\title{
Application of Fungal Biofilm Supported on Activated Carbon for Adsorption of Two Azodyes: Adsorption Kinetics and Isotherms
}

\author{
Asmaa Mawad, Naeima Yousef, Ahmed Shoreit* \\ Botany and Microbiology Department, Faculty of Science, Assiut University, Assiut, Egypt
}

Email address:

ashoreit1968@yahoo.com (A. Shoreit)

To cite this article:

Asmaa Mawad, Naeima Yousef, Ahmed Shoreit. Application of Fungal Biofilm Supported on Activated Carbon for Adsorption of Two Azodyes: Adsorption Kinetics and Isotherms. Advances in Bioscience and Bioengineering. Vol. 3, No. 2, 2015, pp. 11-19.

doi: 10.11648/j.abb.20150302.11

\begin{abstract}
Waste effluents from textile industries, newspaper printing and photography contain residues of dyes and chemicals. Synthetic dyes present in water bodies, even at very low concentrations, can be extremely toxic to the living organisms due to cutting the development of bacteria and preventing the photosynthesis in aqueous flora. Acid Blue 25 (AB25) and Pigment Yellow 101 (PY101) are two types of azodyes which are toxic organic pollutants that consist of both $\mathrm{N}=\mathrm{N}$ and $\mathrm{C}=\mathrm{C}$ chromophoric groups. They cause considerable health effects being irritating to skin, eye and respiratory system and in some cases they may cause cancers. In this study, a biofilm of Aspergillus terreus supported on activated carbon was used as a biological tool for removal of these dyes from water body. The adsorption kinetics and contact time were determined along 240 minutes (30 minute interval). The initial concentration of dyes was $100 \mathrm{mg} / \mathrm{L}$ for each one. The biomass dosage was $1 \mathrm{~g} / \mathrm{L}$. The optimum $\mathrm{pH}$ value for adsorption process was 3.0. The results depicted that the contact time for biosorption of both dyes was 180 min while adsorption kinetics of was quietly fitted with Pseudo second-order kinetics equation models. The maximum adsorption capacity was 82.3 and $78.2 \mathrm{mg} / \mathrm{g}$ for AB 25 and PY 101, respectively. Freundlich model was a good model for adsorption isotherm of two dyes on biofilm.
\end{abstract}

Keywords: Adsorption, Aspergillus terreus, Acid Blue 25, Pigment Yellow 101, Kinetics

\section{Introduction}

The huge number of azodyes are widely produced annually. Dyestuff have variable application in the paper industry, textile, printing and dyehouses. Acid Blue 25 (AB 25) is one of the most applicable anthraquinone azodye in the field of wool and leather dyeing [1]. Pigment Yellow 101 is considered the major fluorescent dye that have limited usage in printing inks viscose dying [2].

The pollution of water resources with industrial effluents containing organic compounds and toxic substances is a matter of great concerns. Industrial dyes are one of aromatic toxic compounds presents in water streams. They cause huge harms to all biota and human due to their complex aromatic structures, resistant to the light and moderate oxidizing agents, high stability and they are usually biologically nondegradable. The industrial dyes may cause skin irritation, mutagenicity and carcinogenicity [3,4]. Thus due to high toxicity, it is necessary to get rid of organic pollutants by proper treatment techniques.

Adsorption has been shown to be the most promising option for all these non-biodegradable organics for the removal from aqueous streams, activated carbons (AC) being the most common adsorbent for this process due to its effectiveness and versatility [5]. By an adsorption process the dye species are transferred to a solid phase (adsorbent) and subsequently can be recovered by a desorption process and stored in a dry place without direct contact with the environment [6]

Activated carbon is the most widely used adsorbent for the removal of color and treatment of textile effluents but due to its high price it is not used on a great scale [7-11]. This has led many workers to search for the use of cheap and efficient alternative materials such as bagasse pith, carbonized bark, peat, soil, tree and eucalyptus barks, chitosan, rice husk, wood and fly ash [12-14]. 
The use of microorganisms as biosorbents is an attractive and alternative methods for toxicity reduction and removal of dyes from industrial effluents because of their good performance and low cost. Dye adsorption studies using microorganisms have been carried out by many researchers. Some microorganisms that have been used as dye adsorbents are Trametes versicolor [15], Rhizopus arrhizus [16], Penicillium sp [17] Aspergillus fumigatus [5], and bacterial consortium [18].

The main objective of this study was (i) determine the cabacity of Aspergillus terreus biofilm supported on activated carbon for adsorption of azodyes, (ii) detect the adsorption kinetics, and the isotherms

\section{Materials and Methods}

\subsection{Adsorbate Preparation}

AB 25 and PY 101 were prepared by dissolving $0.1 \%$ of each one in deionized water separately to detect the maximum absorbance of dyes using UV-Vis Spectrophotometer. Then a serial dilution of each dye from (5-500 $\mathrm{mg} / \mathrm{L})$ were prepared to construct calibration curve at $\lambda \max$.

\subsection{Fungal Strain and Biosorbent Preparation}

AUMC-050 is a fungal isolate that was originally isolated from the textile dye effluent sample. The isolate was identified by Assiut University Mycological Center (AUMC) as Aspergillus terreus based on the color of isolate on solid medium and some biochemical tests. This isolate was lied in the AUMC culture collection as AUMC-050.

The strain AUMC-050 was cultivated on MBS liquid medium amended with $0.2 \%$ glucose under static condition at $28^{\circ} \mathrm{C} 7$-days. The fungal biomass was collected by filtration, washed, oven-dried at $80^{\circ} \mathrm{C}$ for $24 \mathrm{~h}$, powdered and used as a biosorbent. A $20 \mathrm{mg}$ dry weight of the fungal biomass was suspended in $20 \mathrm{~mL}$ of deionized water containing either $(100 \mathrm{mg} / \mathrm{L})$ AB 25 or PY 101.

\subsection{Biofilm Preparation}

The biofilm was prepared by shaking method. Granulated activated carbon (AC) (0.5g) and AUMC-050 cells $(0.5 \mathrm{~g})$ were mixed in deionized water $(500 \mathrm{ml})$ and incubated at $37{ }^{\circ} \mathrm{C}$ for 72 hours under shaking followed by centrifugation, the pellet was dried in an oven at $50{ }^{\circ} \mathrm{C}$, overnight to ensure that the sample was complete drying $[19,20]$.

\subsection{Effect of Contact Time and pH on the Biosorption}

A $20 \mathrm{mg}$ of $A$. terreus biofilm was suspended in $20 \mathrm{ml}$ deionized water consists of AB 25 or PY $101(100 \mathrm{mg} / \mathrm{L})$. Adsorption was carried out at $30^{\circ} \mathrm{C} ; \mathrm{pH} 7.0 \pm 0.2 ; 150 \mathrm{rpm}$ shaking and for $4 \mathrm{hr}$. Deionized water containing $(100 \mathrm{mg} / \mathrm{L})$ dye served as negative control. Samples were withdrawn each 30 minute intervals under aseptic condition. The samples were centrifuged at $10000 \mathrm{rpm}$ for $15 \mathrm{~min}$ and dye concentration of supernatant was determined at $\lambda$ max of each dye by UV-Vis spectrophotometer

The optimum $\mathrm{pH}$ values for biosorption of dyed were determined by analyzing the amount adsorbed $(\mathrm{mg} / \mathrm{g})$ of 20 $\mathrm{ml} \mathrm{AB} 25$ or PY 101 (100 mg/L for each) on $20 \mathrm{mg}$ of biosorbent over a range of $\mathrm{pH} 3.0$ to 8.5 . The $\mathrm{pH}$ was adjusted by $1 \mathrm{M}$ of $\mathrm{KOH}$ and/or $1 \mathrm{M}$ of $\mathrm{HCl}$.

The amount of dye adsorbed at equilibrium $\mathrm{q}_{\mathrm{e}}(\mathrm{mg} / \mathrm{g})$ was analyzed by the following equation:

$$
\mathrm{qe}=(\mathrm{Co}-\mathrm{Ct}) \mathrm{V} / \mathrm{m}
$$

Where $C_{o}$ is the initial concentration of dye $(\mathrm{mg} / \mathrm{L}), \mathrm{C}_{\mathrm{t}}$ is the concentration of dye at time $\mathrm{t}(\mathrm{mg} / \mathrm{L}), \mathrm{V}$ is the total volume of the suspension (L), and $\mathrm{m}$ is the mass of adsorbent (g).

\subsection{Biosorption Kinetics}

In order to investigate the mechanism of biosorption and potential rate controlling steps such as mass transport and chemical reaction processes, kinetic models have been used to test experimental data at constant $\mathrm{pH}$, temperature, dye concentration and contact time. The pseudo first-order and pseudo second-order equations were used in this case, assuming that measured concentrations are equal to cell surface concentrations.

\subsection{Biosorption Isotherm}

Adsorption isotherm was carried out by using different concentration of either AB 25 or PY 101 (25, 50, 100,150, 200 and $300 \mathrm{mg} / \mathrm{L}$ ) at optimal $\mathrm{pH}$ and at $30{ }^{\circ} \mathrm{C}$. The Langmuir and Freundlich models were applied for determine the most suitable one for describe biosorption isotherm of two used dyes at constant temperature.

\section{Results}

\subsection{Removal of Different Azodyes by Different Adsorbent}

The strain AUMC-050, AC and Biofilm of AUMC-050 supported on $\mathrm{AC}$ were separately tested for biosorption of either AB 25 or PY $101(100 \mathrm{mg} / \mathrm{L})$.

The percentage of AB 25 adsorption capacity on AUMC050, AC and Biofilm after 210 min were 52, 70, $82 \%$ (Fig.1), while the percentage of PY 101 removal were 42.1, 56, $78.1 \%$, respectively (Fig. 2).

These results depicted that, the biofilm of $A$. terreus AUMC-050 supported on AC was the most efficient biosorbent for biosorption of $\mathrm{AB} 25$ and PY 101. So, this biofilm was selected for detailed biosorption studies. 


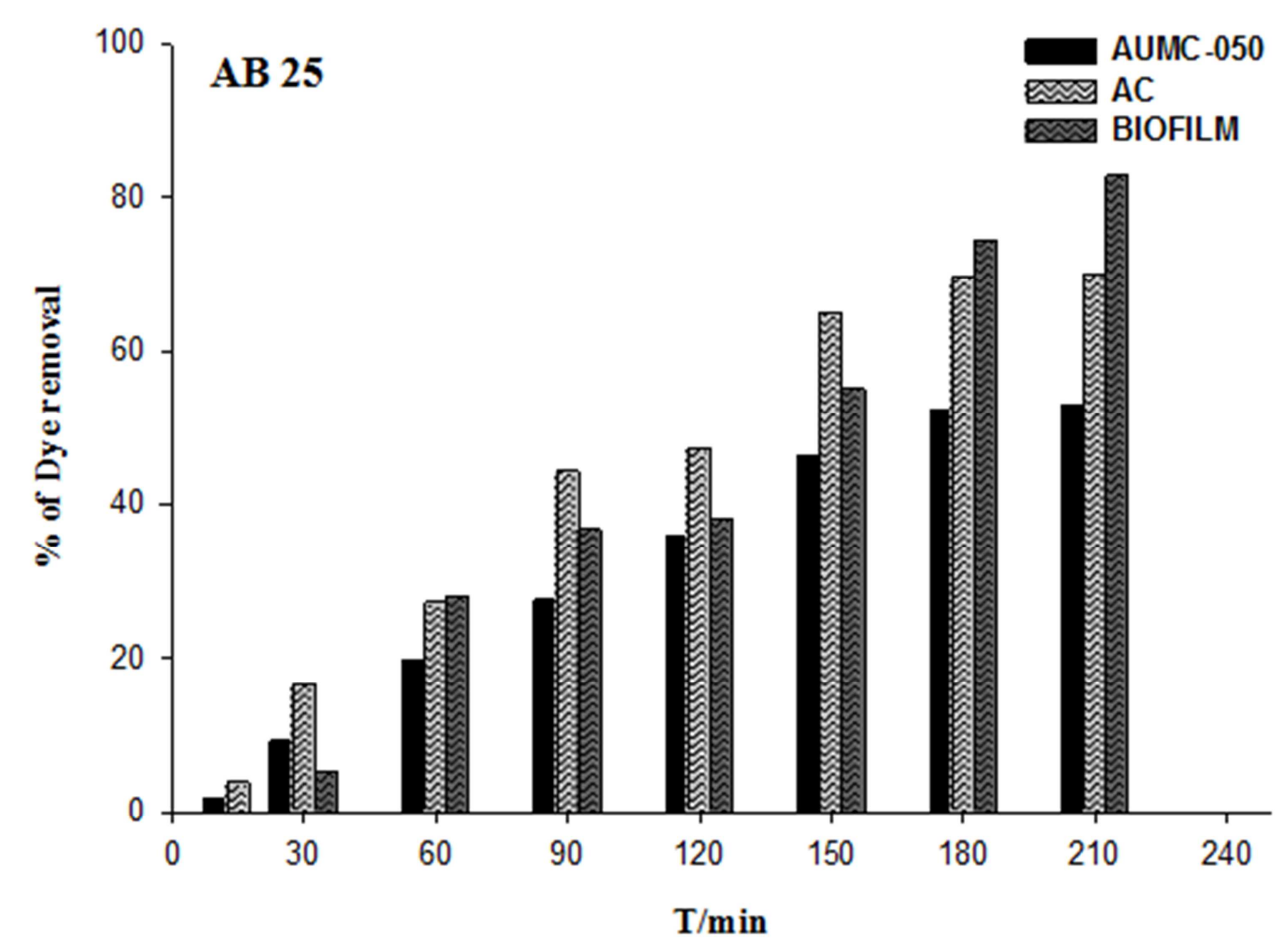

Fig. 1. The percentage of $A B 25$ removal by $A U M C-050, A C$ and a biofilm at initial dye concentration $(100 \mathrm{mg} / \mathrm{L})$ and temperature $30^{\circ} \mathrm{C}$.

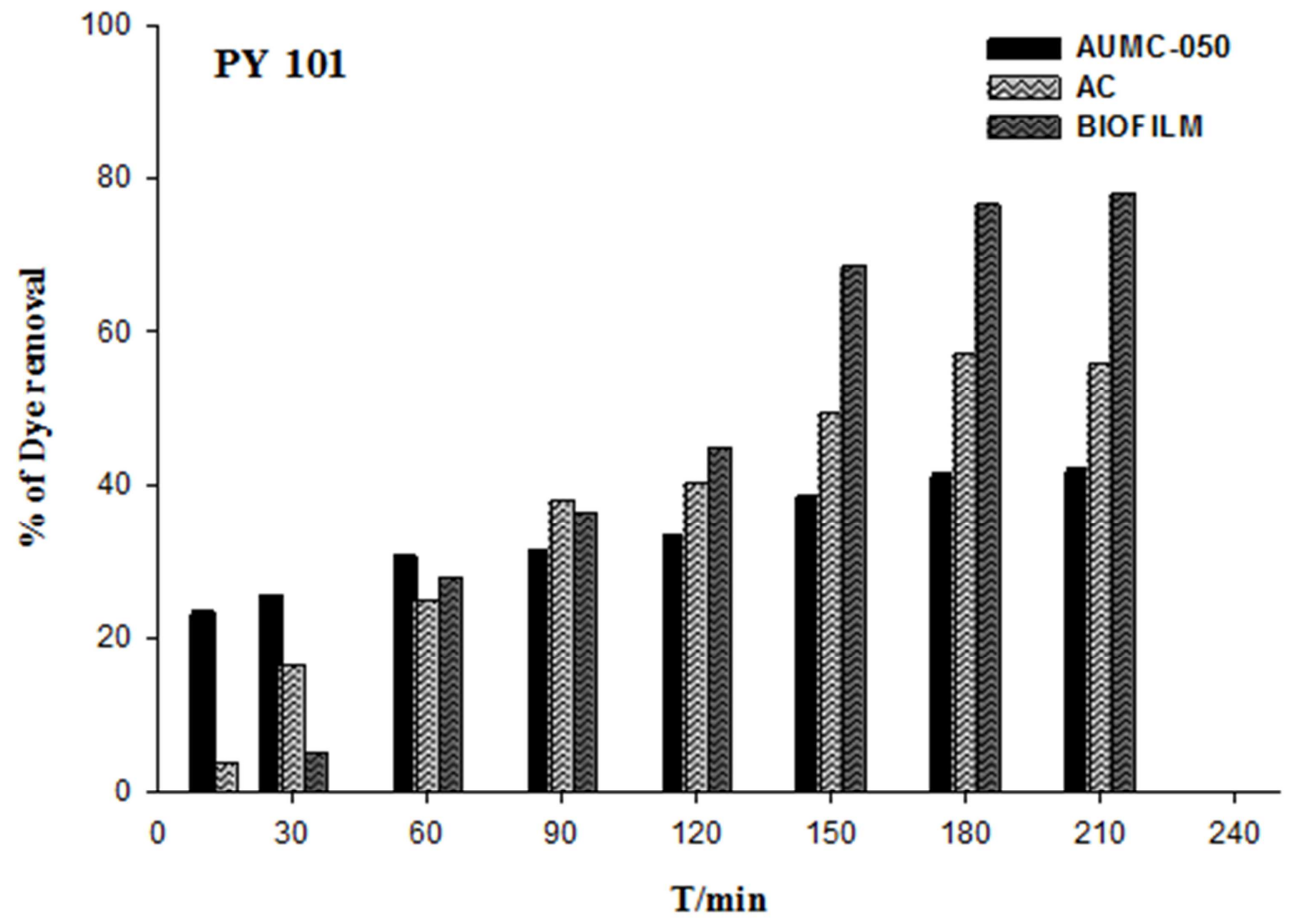

Fig. 2. The percentage of PY 101 removal by AUMC-050, AC and a biofilm at initial dye concentration $(100 \mathrm{mg} / \mathrm{L})$ and temperature $30^{\circ} \mathrm{C}$.

\subsection{Effect of Initial pH on Biosorption Capacity}

The interaction between $\mathrm{pH}$ of the solution, biosorbent surface properties and adsorbate charges controlled the biosorption process. The amount of adsorbed dye $(\mathrm{mg} / \mathrm{g})$ was plotted versus the $\mathrm{pH}$ values from (3.0 to 9). It was observed that, at low $\mathrm{pH}$ value (3.0), the maximum adsorption capacity of AB25 and PY101 was achieved (75.8 and $71.3 \mathrm{mg}$ dye $/ \mathrm{g}$ ), respectively. This level dropped gradually by increasing the $\mathrm{pH}$ value. The minimum value of adsorption capacity was recorded at alkaline $\mathrm{pH}$ values (9.0) (Fig. 3). 


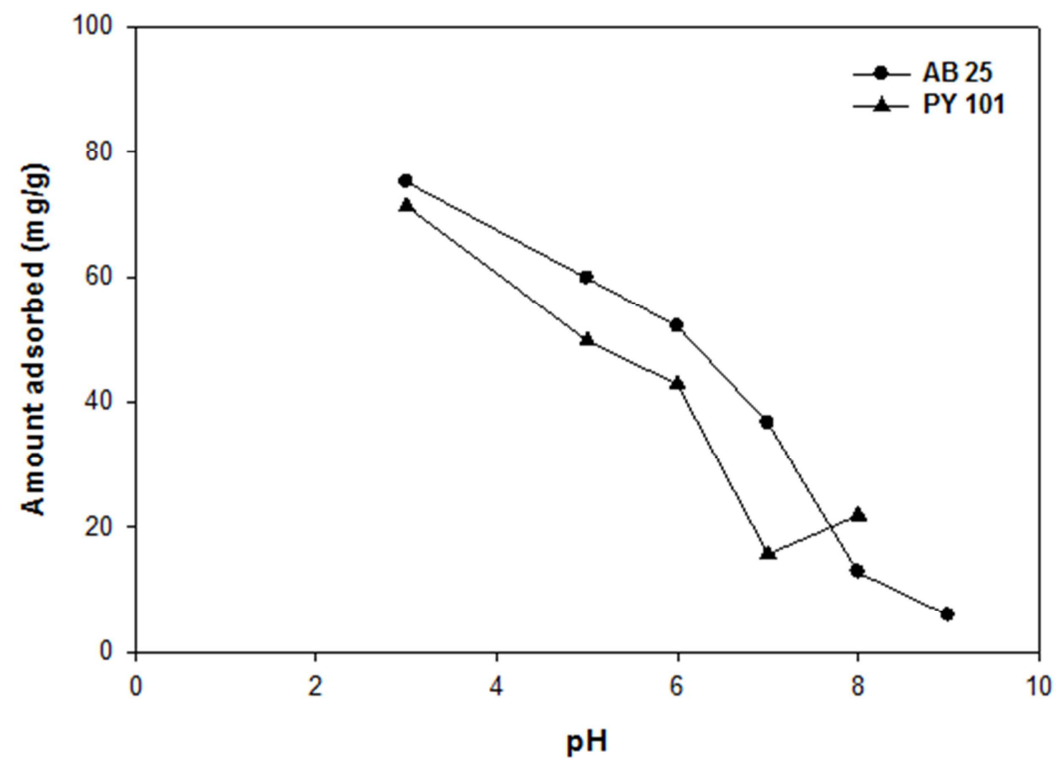

Fig. 3. Effect of $p H$ on the biosorption of $A B 25$ and PY 101 on biofilm of $A$. terreus supported on $A C$. Initial dye concentration $(100 \mathrm{mg} / L) ;$ Temperature $30{ }^{\circ} \mathrm{C}$.

\subsection{Effect of Temperature}

As various textile dye effluents are discharged at relatively high temperatures $(50-60 \mathrm{C})$, so temperature is an important design parameter affecting the biosorption capacity in the real application of biosorption by biomass [21]. To investigate the effect of temperature on the maximum biosorption capacity of AB25 and PY101 onto the dried biofilm, five constant temperatures of 10, 20, 30, 40, 50 and $60{ }^{\circ} \mathrm{C}$ were studied. As shown in Fig.5, the ability of biofilm to adsorb the AB 25 was exceeded its ability to PY101 adsorption at different temperatures. The low temperature $\left(10-20{ }^{\circ} \mathrm{C}\right)$ may decrease the adsorption capacity of dyes. However, the adsorption capacity became at the maximum value 80.2 and $75.4 \mathrm{mg} / \mathrm{g}$ for $\mathrm{AB} 25$ and $\mathrm{PY} 101$ at $40{ }^{\circ} \mathrm{C}$, respectively. The high temperature 50 and $60{ }^{\circ} \mathrm{C}$ significantly decreased the biosorption capacity of $\mathrm{AB} 25$ and completely inhibited the biosorption of PY 101.

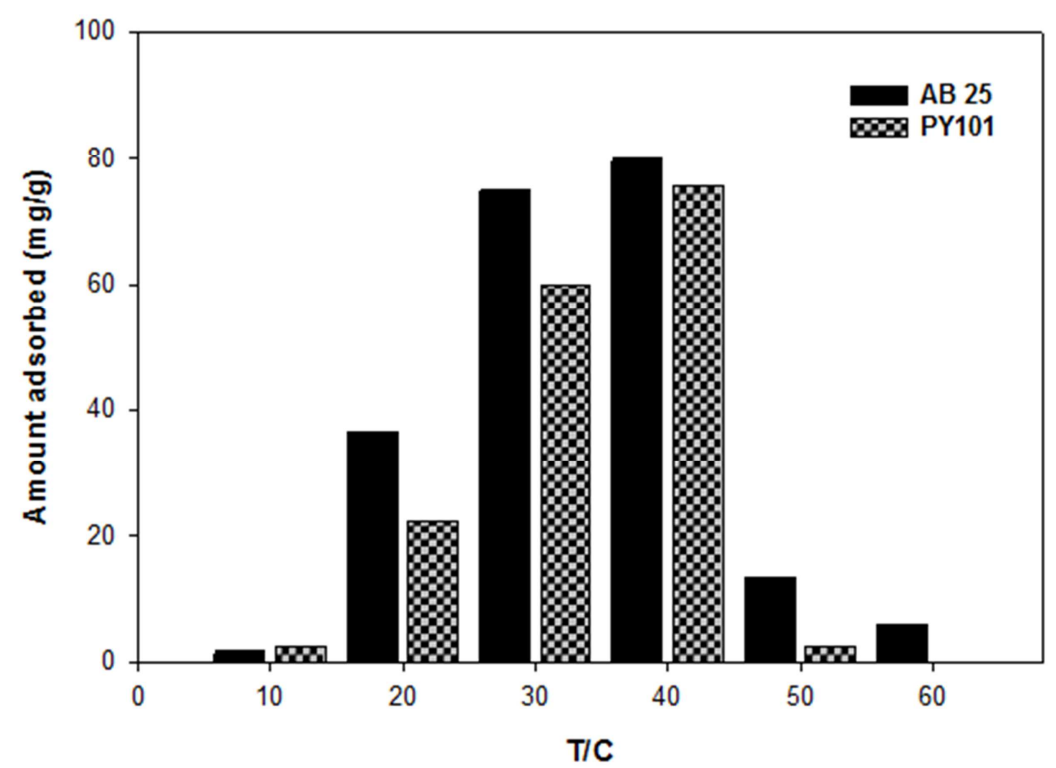

Fig. 4. Effect of temperature on the biosorption of AB 25 and PY 101 on biofilm of A. terreus supported on AC. Initial dye concentration (100mg/L) and pH 3.0.

\subsection{Effect Contact Time on Biosorption of Dyes}

Time is the major parameter which controls any adsorption process. The amount of adsorbent was measured for $210 \mathrm{~min}$ (10 min intervals). The results in Fig. 6 showed that, the figure could be classified into two main regions. The first one, from 0-180 min, the amount adsorption increased gradually by increasing the time to achieve equilibrium at contact time of $150 \mathrm{~min}$ for biosorption of $\mathrm{AB} 25(82.3 \mathrm{mg} / \mathrm{g})$. On the other hand, the maximum adsorption capacity for PY 101 was $78.2 \mathrm{mg} / \mathrm{g}$ at contact time $180 \mathrm{~min}$. The second region were from 180-210 min, this region could be called static 
adsorption region at which there were any increase in the amount adsorption along the time.

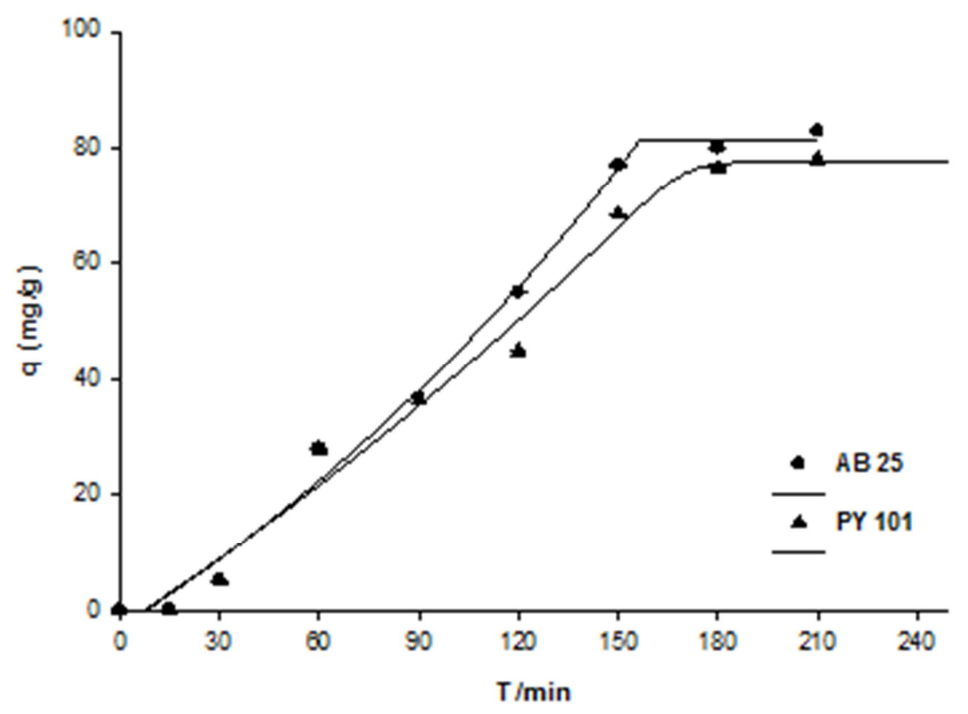

Fig. 5. The effect of contact time on biosorption of AB 25 and PY 101 using biofilm Initial concentration (100mg/L); Temperature $30^{\circ} \mathrm{C}$; $\mathrm{pH} 3$.

\subsection{Biosorption Kinetics}

It is very important to determine the biosorption kinetics to investigate which model is more suitable for biosorption process. . The kinetics parameter of adsorption is determined by Pseudo first-order [22] which expressed as the following

$$
\log \left(\mathrm{q}_{\mathrm{e}}-\mathrm{q}_{\mathrm{t}}\right)=\log \mathrm{q}_{\mathrm{e}}-\mathrm{k}_{1} \mathrm{t} / 2.303
$$

Where $\mathrm{k}_{1}$ is the pseudo first-order rate constant and $\mathrm{q}_{\mathrm{e}}$ and $\mathrm{q}_{\mathrm{t}}$ are the adsorption capacity of the dye molecules on adsorbent at equilibrium and at time $t$, respectively. The values of $\mathrm{k}_{1}$ and $\mathrm{q}_{\mathrm{e}}$ were evaluated by plotting $\log \left(\mathrm{q}_{\mathrm{e}}-\mathrm{q}_{\mathrm{t}}\right)$ versus the time and the calculated qe were demonstrated in Fig.6. The results showed that, the calculated qe were 13.7 and $6.8 \mathrm{~g} / \mathrm{mg}$ for biosorption of $\mathrm{AB} 25$ and PY 101 on the biofilm. The value of $\mathrm{K}_{1}$ and correlation co-efficient were summarized in Table 1. This result was not consistent with the experimental results so, the pseudo first-order was unconvincing model to describe the biosorption kinetics.

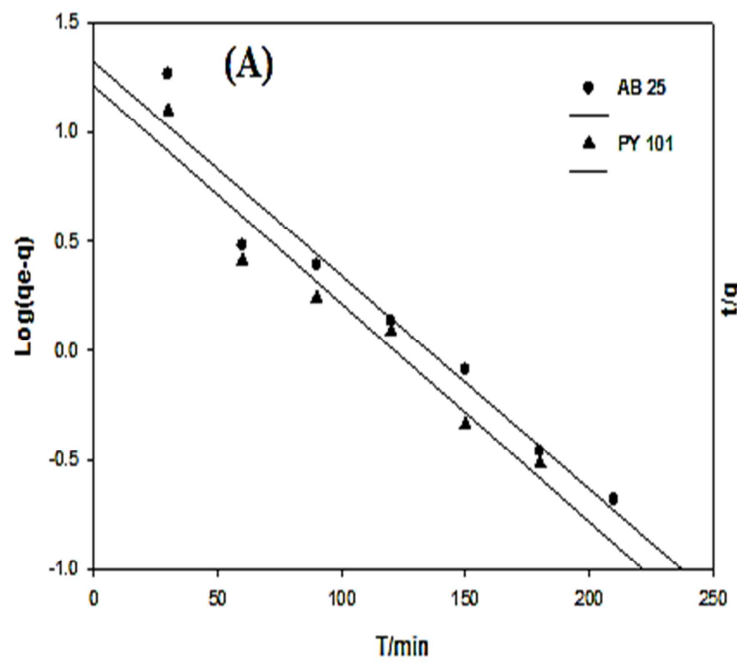

The linear pattern of pseudo second-order kinetics is presented by the equation

$$
\mathrm{t} / \mathrm{q}_{\mathrm{t}}=1 / \mathrm{k}_{2} \mathrm{qe}^{2}+\mathrm{t} / \mathrm{q}_{\mathrm{e}}
$$

Where $\mathrm{k}_{2}$ is the pseudo second-order adsorption rate constant.. The values of $\mathrm{k}_{2}$ and $\mathrm{q}_{\mathrm{e}}$ were estimated from the slope and intercept of plots of t/qe versus t Fig. 7 and exhibited in Table 1.

It is observed that, although the $r^{2}$ value of biosorption of AB 25 was less than the pseudo first-order kinetics model, the estimated qe $(90.2 \mathrm{mg} / \mathrm{g})$ was highly closed to the experimental one $(82.3 \mathrm{mg} / \mathrm{g})$. Also, the estimated qe $(81.6$ $\mathrm{mg} / \mathrm{g}$ ) value for PY 101 biosorption was much closed to the experimental one $(78.2 \mathrm{mg} / \mathrm{g})$. The calculated $\mathrm{K}_{2}$ and $\mathrm{r}^{2}$ were listed in Table1.

The results showed that the Pseudo second-order model was the most suitable model for description of adsorption kinetics of two used dyes.

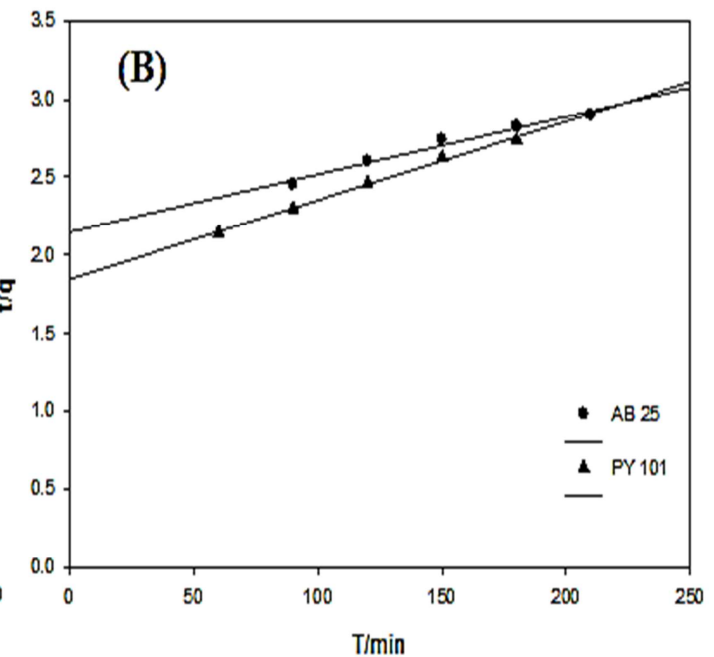

Fig. 6. Pseudo first- order (A) and Pseudo-second order (B) models for adsorption kinetics of AB 25 and PY 101 on the Biofilm. 
Table 1. Biosorption kinetics parameters by Pseudo first-order and Pseudo second-order models for adsorption of AB25 and PY 101 on the biofilm.

\begin{tabular}{|c|c|c|c|c|c|c|c|}
\hline \multirow{2}{*}{ Adsorbate } & \multirow{2}{*}{$\mathbf{q} \mathbf{e}_{\text {(exp) mg/g }}$} & \multicolumn{3}{|c|}{ Pseudo first-order } & \multicolumn{3}{|c|}{ Pseudo second-order } \\
\hline & & $\mathrm{q}_{\mathrm{e} \text { (cal) }}(\mathrm{mg} / \mathrm{g})$ & $\mathbf{K}_{1}$ & $\mathbf{r}^{2}$ & $q_{\text {e (cal) }}(\mathrm{mg} / \mathrm{g})$ & $\mathbf{K}_{2}$ & $\mathbf{r}^{2}$ \\
\hline $\mathrm{AB} 25$ & 81.2 & $22.4 \pm 1.8$ & $0.022 \pm 0.014$ & 0.94 & $76.9 \pm 0.81$ & $0.008 \pm 0.05$ & 0.97 \\
\hline PY 101 & 77.3 & $15.8 \pm 0.25$ & $0.023 \pm 0.02$ & 0.95 & $70.1 .6 \pm 2.5$ & $0.002 \pm 0.042$ & 0.98 \\
\hline
\end{tabular}

\subsection{Biosorption Isotherm}

Different isotherm models were used to determine the biosorption characteristics of the biofilm. In this study, Langmuir and Freundlich models were applied.

The fundamental assumption of the Langmuir isotherm model is that biosorption takes place at specific sites within the biosorbent. Once a biosorbate occupies a binding site, no further biosorption occurs at this site. Meaning that the process is monolayer biosorption. The linear form of Langmuir is expressed as the following [23]

\section{$\mathrm{Ceq} / \mathrm{qe}=1 / \mathrm{qmaxb}+\mathrm{ceq} / \mathrm{qmax}$}

Where $\mathrm{b}$ is the Langmuir constant $\left(\mathrm{dm}^{3} / \mathrm{mg}\right)$ related to affinity between adsobate and adsorbent and qmax is the maximum monolayer adsorption capacity $(\mathrm{mg} / \mathrm{g})$. The values of qmax and $b$ also give an indication of the affinity of the dye for binding sites on the biosorbent. These values are calculated from the slope and intercept of the linear plot of $\mathrm{C}_{\mathrm{e}} / \mathrm{q}_{\mathrm{e}}$ against $\mathrm{C}_{\mathrm{e}}$ as shown in (Fig. 8A). The Langmuir parameters are presented in Table 2. The calculated qmax were 100 and $88 \mathrm{mg} / \mathrm{g}$ for for biosorption of $\mathrm{AB} 25$ and PY 101 .
It was observed that the calculated values of qmax were closed to the experimental value of qe (Fig. 7). The correlation co-efficient of AB 25 and PY 101 were 0.88 and 0.998 meaning that, the Langmuir model was a more favorable model for the biosorption of PY 101 but it was unsuitable for AB 25.

The Freundlich isotherm is an empirical equation based on biosorption on heterogeneous surface and also possibly in multi- layer biosorption. Linear form of the Freundlich equation [24]

$$
\ln \text { qeq }=(1 / \mathrm{n}) \operatorname{lnCeq}+\ln \mathrm{Kf}
$$

Where, $\mathrm{K}_{\mathrm{f}}\left(\mathrm{dm}^{3} / \mathrm{g}\right)$ and $\mathrm{n}$ are the adsorption capacity and the intensity of adsorption, respectively. Freundlich parameters can be determined from the linear form of the equation. By plotting the lnqe versus $\operatorname{lnCe}$, the slope is the value of $1 / \mathrm{n}$ and the intercept is equal to $\ln _{\mathrm{f}}$. The linear form of the Freundlich equation was shown in Fig. 9B. Freundlich adsorption parameters are illustrated in Table 2. The correlation co-efficient of AB 25 and PY 101 were 0.95 and 0.97 . Thus, it could be interpreted that the model of Freundlich was efficient to describe the biosorption of the used dyes on the surface of the biofilm.

Table 2. Langmuir and Freundlich isotherm parameters for adsorption of AB25 and PY 101 on the biofilm.

\begin{tabular}{|c|c|c|c|c|c|c|c|}
\hline \multirow{2}{*}{ Adsorbate } & \multirow{2}{*}{ Qe exprimental } & \multicolumn{3}{|l|}{ Langmuir } & \multicolumn{3}{|l|}{ Freundlich } \\
\hline & & $Q_{\max }(\mathrm{mg} / \mathrm{g})$ & $B\left(\mathrm{dm}^{3} / \mathrm{mg}\right)$ & $r^{2}$ & $K_{F}\left(d^{3} / m g\right)$ & $\mathbf{N}$ & $\mathbf{r}^{2}$ \\
\hline $\mathrm{AB} 25$ & $102 \pm 0.25$ & $100 \pm 1.8$ & $0.035 \pm 0.001$ & 0.88 & 3.98 & $1.25 \pm 0.85$ & 0.95 \\
\hline PY 101 & $85 \pm 0.5$ & $88 \pm 5.1$ & $0.121 \pm 0.012$ & 0.99 & 1513.6 & $3.6 \pm 0.42$ & 0.97 \\
\hline
\end{tabular}

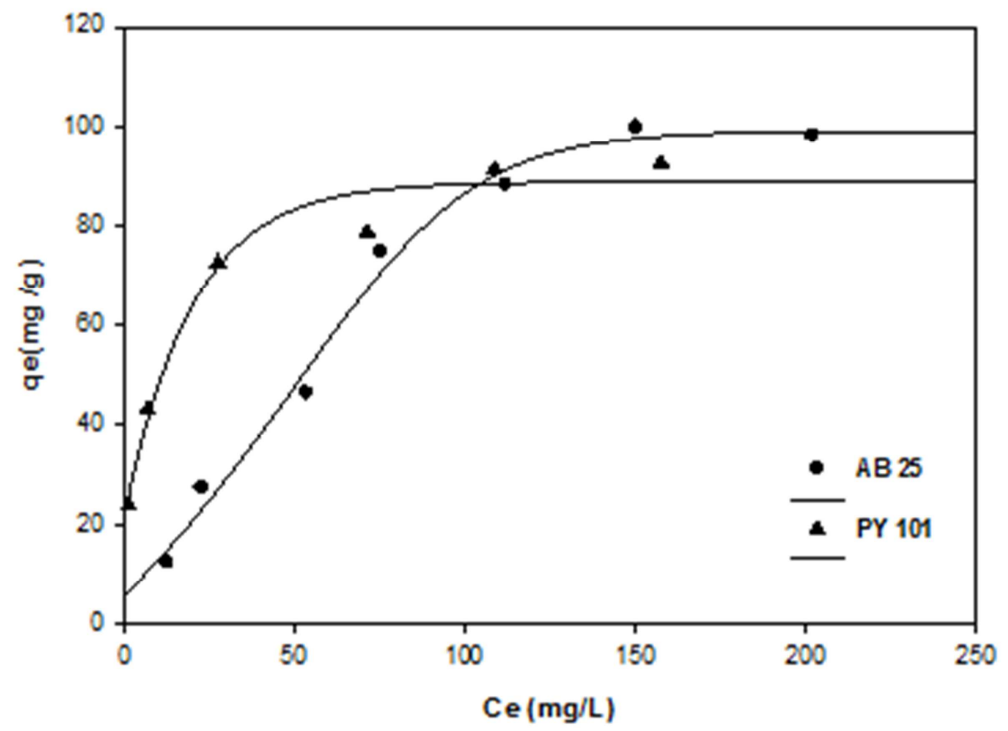

Fig. 7. The experimental plot of biosorption isotherm of $A B 25$ and $P Y 101$ on the Biofilm at different concentration of dyes, at $T=30^{\circ} \mathrm{C}$ and $p H=3.0$. 

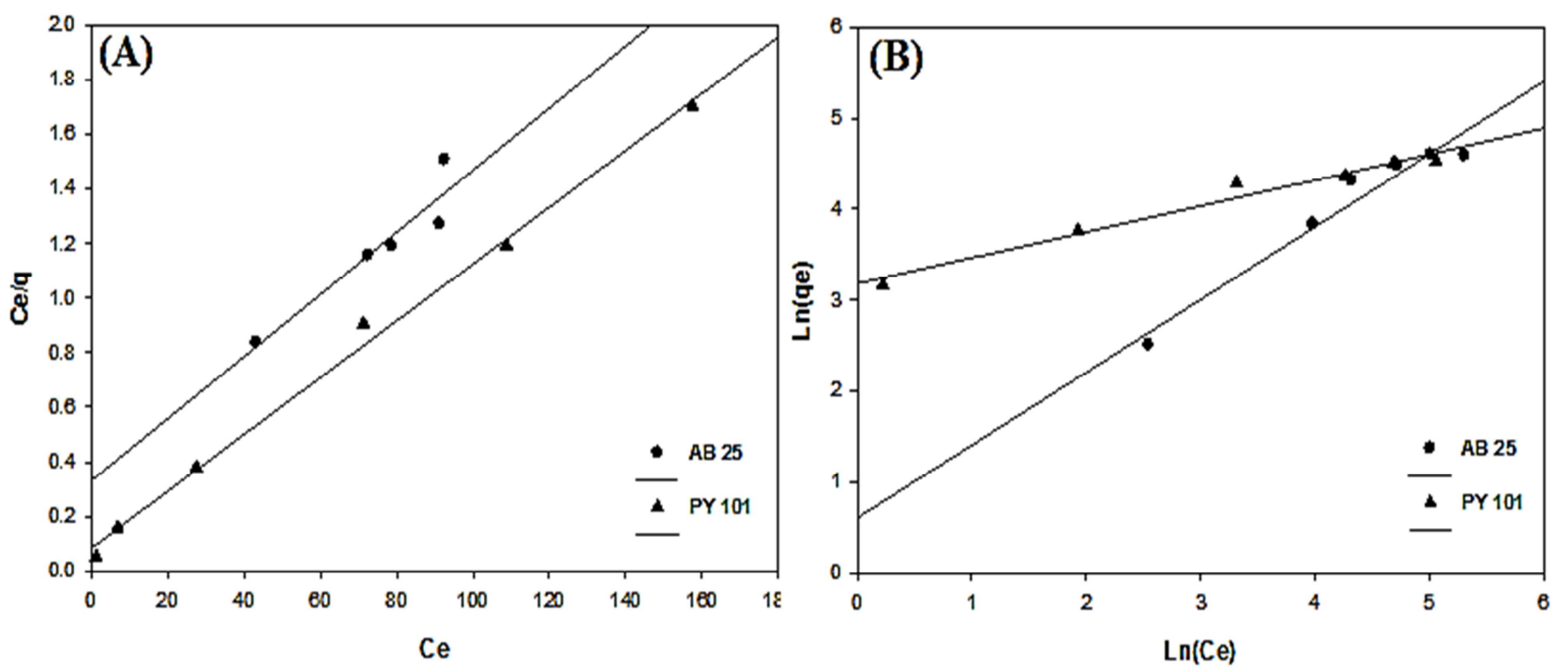

Fig. 8. Linear form of Langmuir (A) and Freundlich (B) models for AB 25 and PY 101 biosorption on the Biofilm.

\section{Discussion}

Adsorption has been shown to be the most promising option for removal of different non-biodegradable compounds from aqueous streams. Activated carbons are the most common adsorbent for this procedure due to its potency and versatility. Activated carbons are usually obtained from materials with a high carbon content and possess a great adsorption capacity, which is mainly determined by their porous structure [8].

Another promising technology used in removal of dyes is microbial biofilm supported on granular activated carbon. The role of biomass supported on carbonaceous material like the activated carbon has a great advantages, especially, if the dye-containing effluent is very toxic [25]. Biomass adsorption is effective when conditions are not always favorable for the growth and maintenance of the microbial population [26].

A. terreus cell wall is mainly constituted of functional groups like carboxyl, sulfate and amine. In acidic solutions the protonation of amine functions allows the electrostatic attraction of dye molecules that are negatively charged (anionic groups). This attraction mechanism between anionic dyes and cationic surface of the biomass in acidic solutions may explain the higher efficiency of dye biosorption at $\mathrm{pH}$ 2.0 [27]. Because hydrogen ion acts as a bridging ligand between the fungal cell wall and the dye molecule. By increasing the $\mathrm{pH}$ value this mechanism become weak due to the deprotonation of amine group which reduce the affinity of A. terreus to dyes. After $\mathrm{pH} 6.0$ the carboxylic became negatively charged which consequently increase the electrostatic repulsion between anionic dye and the anionic reactive groups [28]. So, it could be said that adsorption by biomass occurs by ion exchange. This result agreed with the studies of biosorption behaviors of different anionic dyes by Aspergillus fumigatus and Penicillium restrictum [5, 29].

The temperature has two main effects on the adsorption processes. Increasing temperature is known to increase the diffusion rate of the adsorbate molecules within the pores as a result of decreasing solution viscosity and will also modify the equilibrium capacity of the adsorbent for a particular adsorbate [30]. High temperature may increase the diffusion rate of adsorbate through the biosorbent's pore due to decrease the viscosity of solution. Increasing temperature caused an increase in the number molecules acquiring sufficient energy to undergo chemical reaction which shows chemisorption [31]. As various textile dye effluents are discharged at relatively high temperatures (50-60 C), so temperature is an important design parameter affecting the biosorption capacity in the real application of biosorption by biomass [21].

Chu and Chen $[32,33]$ studied the effect of temperature on biosorption of Basic Violet 3 and Basic Yellow 24 dyes using dried activated sludge biomass and they observed that, adsorption capacity decreased from 113.6 to $109.8 \mathrm{mg} \mathrm{g}$ for Basic Violet 3 and decreased from 57.0 to $51.3 \mathrm{mg} / \mathrm{g}$ for Basic Yellow 24 with increasing temperature from 20 to $40{ }^{\circ} \mathrm{C}$. These results indicated that both biosorption processes are exothermic in nature.

Regarding to the contact (equilibrium) time, the dynamic changes in biosorption along the time explained that there were difference between charge density and topography and/or surface area of used biosorbant $[34,35]$, or by the resistance to intraparticle diffusion [36]. The first rapid increase may involve physical adsorption or ion exchange at cell surface and the subsequent slower phase may involve other mechanisms such as complexation, micro-precipitation or saturation of binding sites [34, 35]. Pseudomonas pseudoalcaligenes could remove $50 \mathrm{mg} / \mathrm{g}$ of initial concentration of $\mathrm{AB} 25(100 \mathrm{mg} / \mathrm{L})$ within $180 \mathrm{~min}$ equilibrium time [37].

Information on the kinetics of dye adsorption is required for selecting optimum operating conditions for full-scale batch dye removal processes. Mathematical models that can 
describe the behavior of a batch biosorption process operated under different experimental conditions are very useful for scale-up studies or process optimization [38]. Adsorption kinetics explains how fast the sorption process occurs and also the factors affecting the reaction rate. The nature of sorption will depend on the physical or chemical characteristics of the adsorbent system and also on the system conditions [17].

Many kinetic models have been used to explain the reaction order of the system. In the present investigation the sorption data were analyzed using simplest kinetic models such as Langmuir, Freundlich, pseudo first and second order models. The data depicted that Freundlich isotherm models were suitable for biosorption of AB25 anf PY 101. By increasing the concentration of dye the adsorption capacity is increasing. Because at low concentration of dye the fast saturation of surface due to fast uptake of dye on the other hand at high concentration dyes molecules need to diffuse on the surface of biosorbent and highly hydrolyzed molecules will be diffused with slow rate [39].

It could be concluded that, the biofilm of $A$. terreus supported on activated carbon (AC) enhance the biosorption of two different azodyes AB 25 and PY 101 rather than $A$. terreus or AC alone. The model of Pseudo second-order was the most suitable model for description the adsorption kinetics while the Freundlich model was the best one for adsorption isotherm. Also, the ability of the biofilm for biosorption of $\mathrm{AB} 25$ was higher than its ability for biosorption of PY 101. This may be due to the chemical structure of PY 101 is more complicated than AB 25. Compatibility between microorganism and activated carbon in the form of biofilm may enhance the capacity of dye biosoprtion.

\section{Acknowledgment}

The authors have a great thankful for Prof. Dr. Abd Elaal Mobashir for his efforts in identification of the strain. Also a great thankful to Dr. Sedky Hassan for helping in understanding biosorption calculations.

\section{References}

[1] H. Ghodbane, O. Hamdaoui, Intensification of sonochemical decolorization of anthraquinonic dye Acid Blue 25 using carbon tetrachloride, Ultrasonics sonochemistry, 16 (2009) 455-461.

[2] A. Dreuw, J. Plötner, L. Lorenz, J. Wachtveitl, J.E. Djanhan, J. Brüning, T. Metz, M. Bolte, M.U. Schmidt, Molecular Mechanism of the Solid-State Fluorescence Behavior of the Organic Pigment Yellow 101 and Its Derivatives, Angewandte Chemie International Edition, 44 (2005) 7783-7786.

[3] C. Wang, A. Yediler, D. Lienert, Z. Wang, A. Kettrup, Ozonation of an azo dye CI Remazol Black 5 and toxicological assessment of its oxidation products, Chemosphere, 52 (2003) 1225-1232.
[4] J.J. Soriano, J. Mathieu-Denoncourt, G. Norman, S.R. de Solla, V.S. Langlois, Toxicity of the azo dyes Acid Red 97 and Bismarck Brown $\mathrm{Y}$ to Western clawed frog (Silurana tropicalis), Environmental Science and Pollution Research, 21 (2014) 3582-3591.

[5] B.-E. Wang, Y.-Y. Hu, L. Xie, K. Peng, Biosorption behavior of azo dye by inactive CMC immobilized Aspergillus fumigatus beads, Bioresource Technology, 99 (2008) 794-800.

[6] N. Sheng, M. Li, Y. Wang, Study on affecting factors of biosorption of MoO 4 2- by Pseudomonas Pseudoalcaligenes, in: Multimedia Technology (ICMT), 2011 International Conference on, IEEE, 2011, pp. 1231-1234.

[7] Z. Aksu, S. Tezer, Biosorption of reactive dyes on the green alga Chlorella vulgaris, Process Biochemistry, 40 (2005) 1347-1361.

[8] L. Sun, Y. Yao, L. Wang, Y. Mao, Z. Huang, D. Yao, W. Lu, W. Chen, Efficient removal of dyes using activated carbon fibers coupled with 8-hydroxyquinoline ferric as a reusable Fentonlike catalyst, Chemical Engineering Journal, 240 (2014) 413419 .

[9] S. Dağdelen, B. Acemioğlu, E. Baran, O. Koçer, Removal of Remazol Brilliant Blue R From Aqueous Solution by Pirina Pretreated with Nitric Acid and Commercial Activated Carbon, Water, Air, \& Soil Pollution, 225 (2014) 1-15.

[10] H. Sayğılı, F. Güzel, Y. Önal, Conversion of grape industrial processing waste to activated carbon sorbent and its performance in cationic and anionic dyes adsorption, Journal of Cleaner Production, (2015).

[11] I.A. Aguayo-Villarreal, V. Hernandez-Montoya, A. BonillaPetriciolet, R. Tovar-Gomez, E.M. Ramirez-Lopez, M.A. Montes-Moran, Role of acid blue 25 dye as active site for the adsorption of $\mathrm{Cd}^{+2}$ and $\mathrm{Zn}^{+2}$ using activated carbons, Dyes and Pigments, 96 (2013) 459-466.

[12] L. Morais, O. Freitas, E. Goncalves, L. Vasconcelos, C.G. Beca, Reactive dyes removal from wastewaters by adsorption on eucalyptus bark: variables that define the process, Water Research, 33 (1999) 979-988.

[13] K.R. Ramakrishna, T. Viraraghavan, Dye removal using low cost adsorbents, Water Science and Technology, 36 (1997) 189-196.

[14] A. Ahmad, A. Idris, B. Hameed, Modeling of disperse dye adsorption onto bamboo-based activated carbon in fixed-bed column, Desalination and Water Treatment, 52 (2014) 248256.

[15] G. Cengiz, P. Aytar, M. Şam, A. Çabuk, Removal of reactive dyes using magnetically separable Trametes versicolor cells as a new composite biosorbent, Separation Science and Technology, 49 (2014) 1860-1871.

[16] Z. Aksu, Ş.Ş. Çağatay, Investigation of biosorption of Gemazol Turquise Blue-G reactive dye by dried Rhizopus arrhizus in batch and continuous systems, Separation and Purification Technology, 48 (2006) 24-35.

[17] O. Anjaneya, M. Santoshkumar, S.N. Anand, T. Karegoudar, Biosorption of acid violet dye from aqueous solutions using native biomass of a new isolate of Penicillium sp, International Biodeterioration \& Biodegradation, 63 (2009) $782-787$. 
[18] A.A. Telke, A.A. Kadam, S.P. Govindwar, Bacterial Enzymes and Their Role in Decolorization of Azo Dyes, in: Microbial Degradation of Synthetic Dyes in Wastewaters, Springer, 2015, pp. 149-168.

[19] J. Rivera-Utrilla, I. Bautista-Toledo, M.A. Ferro-García, C. Moreno-Castilla, Activated carbon surface modifications by adsorption of bacteria and their effect on aqueous lead adsorption, Journal of Chemical Technology and biotechnology, 76 (2001) 1209-1215.

[20] R.M. Gabr, S.M. Gad-Elrab, R.N. Abskharon, S.H. Hassan, A.A. Shoreit, Biosorption of hexavalent chromium using biofilm of E. coli supported on granulated activated carbon, World Journal of Microbiology and Biotechnology, 25 (2009) 1695-1703.

[21] I.M. Banat, P. Nigam, D. Singh, R. Marchant, Microbial decolorization of textile-dyecontaining effluents: a review, Bioresource Technology, 58 (1996) 217-227.

[22] S. Largergren, Zur theorie der sogenannten adsorption geloster stoffe. Kungliga Svenska Vetenskapsakademiens, Handlingar, 24 (1898) 1-39.

[23] I. Langmuir, The adsorption of gases on plane surfaces of glass, mica and platinum, Journal of the American Chemical society, 40 (1918) 1361-1403.

[24] U. Freundlich, Die adsorption in lusungen, (1906).

[25] Y. Miao, Biological remediation of dyes in textile effluent: a review on current treatment technologies, in, 2005.

[26] S. Ong, E. Toorisaka, M. Hirata, T. Hano, Combination of adsorption and biodegradation processes for textile effluent treatment using a granular activated carbon-bioflm confgured packed column system, Journal of Environmental Sciences, 20 (2008) 952-956.

[27] A.R. Binupriya, M. Sathishkumar, C.S. Ku, S.-I. Yun, Sequestration of Reactive Blue 4 by free and immobilized Bacillus subtilis cells and its extracellular polysaccharides, Colloids and Surfaces B: Biointerfaces, 76 (2010) 179-185.

[28] K. Azlan, W.N. WAN SAIME, L. LAI KEN, Chitosan and chemically modified chitosan beads for acid dyes sorption, Journal of Environmental Sciences, 21 (2009) 296-302.

[29] C.F. Iscen, I. Kiran, S. Ilhan, Biosorption of Reactive Black 5 dye by Penicillium restrictum: The kinetic study, Journal of hazardous materials, 143 (2007) 335-340.

[30] M. Doğan, Y. Özdemir, M. Alkan, Adsorption kinetics and mechanism of cationic methyl violet and methylene blue dyes onto sepiolite, Dyes and Pigments, 75 (2007) 701-713.

[31] J.Y. Farah, N.S. El-Gendy, L.A. Farahat, Biosorption of Astrazone Blue basic dye from an aqueous solution using dried biomass of Baker's yeast, Journal of hazardous materials, 148 (2007) 402-408.

[32] H. Chu, K. Chen, Reuse of activated sludge biomass: I. Removal of basic dyes from wastewater by biomass, Process Biochemistry, 37 (2002) 595-600.

[33] H. Chu, K. Chen, Reuse of activated sludge biomass: II. The rate processes for the adsorption of basic dyes on biomass, Process Biochemistry, 37 (2002) 1129-1134.

[34] E. Daneshvar, M. Kousha, M.S. Sohrabi, A. Khataee, A. Converti, Biosorption of three acid dyes by the brown macroalga Stoechospermum marginatum: Isotherm, kinetic and thermodynamic studies, Chemical Engineering Journal, 195 (2012) 297-306.

[35] V. Gupta, A. Rastogi, Biosorption of hexavalent chromium by raw and acid-treated green alga Oedogonium hatei from aqueous solutions, Journal of Hazardous Materials, 163 (2009) 396-402.

[36] Z. Aksu, S. Tezer, Biosorption of reactive dyes on the green alga Chlorella vulgaris, Process Biochemistry, 40 (2005) 1347-1361.

[37] A.M.M. Mawad, N.M.H. Yousef, A.A.M. Shoreit, Bioremediation of Acid blue 25 dye by anthracene degrading Pseudomonas pseudoalcaligenes ASU-016, CATRINA 10 (2015) $53-60$.

[38] M.A.K.M. Hanafiah, W.S.W. Ngah, S.H. Zolkafly, L.C. Teong, Z.A.A. Majid, Acid Blue 25 adsorption on base treated Shorea dasyphylla sawdust: Kinetic, isotherm, thermodynamic and spectroscopic analysis, Journal of Environmental Sciences, 24 (2012) 261-268.

[39] J.-H. Joo, S.H. Hassan, S.-E. Oh, Comparative study of biosorption of $\mathrm{Zn}^{+2}$ by Pseudomonas aeruginosa and Bacillus cereus, International Biodeterioration \& Biodegradation, 64 (2010) 734-741. 